\title{
The Possibility of a 'Dead Europe': Tsiolkas, Houellebecq and European Mythologies
}

\author{
Nicholas Manganas, University of Technology Sydney
}

\section{Introduction}

This article posits that two constituent mythologies sustain and drive the European Union (EU) integration process. The first is the tension between the twin narratives of 'perpetual peace' and 'perpetual suffering.' The narrative script of 'perpetual peace' promotes post-Communist Europe as a post-historical paradise. Paradoxically, this narrative can only function in tandem with the inverse narrative of 'perpetual suffering,' a narrative script that argues that Europe is the continent that carries the burden and pain of the twentieth century. The second fundamental mythology of the EU project is the tension between the narratives of Europe as, on the one hand 'authentic' and as 'cosmopolitan' on the other. By authenticity I am referring to the rich and diverse cultural traditions of the European continent. This narrative script argues that the quaint, parochial and national traditions of the past are successfully functioning side by side with a modern cosmopolitan Generation E sensibility (Reid 2005, 3). Both of these constituent mythologies are essential in forming what is emerging as a pan-European, Europtimist raison d'etre. However, although this article considers these narratives to be powerful, it does not regard them as all-encompassing. In this article I argue that two recent novels, the Australian Christos Tsiolkas’s Dead Europe (2005), and the French Michel Houellebecq's The Possibility of an Island (2006), subvert these two mythologies, in the process undermining the legitimacy of recent works of Europtomist scholarship. 


\section{Whose Europe?}

In 2005 Christos Tsiolkas published Dead Europe, a novel that sought to subvert the European imaginary landscape from a Greek-Australian perspective-born in Australia, his parents were Greek immigrants-by issuing a challenge to Europeans from the Antipodes: Europe, you are absent of life. Former US Secretary of Defence Donald Rumsfeld was taken to task for dividing Europe into 'old' and 'new,' but Tsiolkas is after the knock-out punch: Europe, you are not even alive. With what legitimacy can Tsiolkas, an outsider, discuss the big themes of our time-history, migration, blood, belonging, poverty, refuge, anti-Semitism — in such a European and realist fashion (Syson 2005, 4)? In America Jean Baudrillard wrote, 'Europe can no longer be understood by starting out from Europe itself' $(1988,98)$, and Tsiolkas starts his story on the other side of the world in suburban Melbourne.

Dead Europe tells the story of Isaac, a Greek-Australian photographer invited to Athens to help celebrate the culture of the Greek diaspora. His exhibition makes a dismal understatement and he is overwhelmed by the changes that have taken place in Greece and the rest of Europe. The wave of hope that Isaac experienced when he was last in Europe in the aftermath of the fall of the Berlin Wall has evaporated. Instead, he encounters empty villages drained of their former 'life,' and a new amoral generation of Europeans living in what are now global, cosmopolitan and connected cities. Isaac sets off on a journey across post-Communist Europe, and to cities such as Prague, Paris and Oxford, taking photographs that seem to chronicle the decay of post-1989, postideological Europe. His photographs chronicle his travels but something mysterious and surreal haunt his photographs. According to Isaac:

\footnotetext{
Death in a photograph is not merely a matter of focus or of composition. It is not only the light. It is not the subject. There are photographs that are blurred or ugly or too dark or over-exposed, they can be banal or boring or incompetent. But that does not necessarily make them dead. Death is, of course, simply the absence of life, of the heart and the blood and the soul. The absence of fluid and flesh. The eyes that stared back at me from my photos were dead. The trees, and asphalt streets, dead. All my subjects were muted and still. Not calm, but inert. The absence of motion. I would emerge from the darkroom every time, and the smell of chemicals was death on my skin, on my hands. (46)
}

The sustained metaphor of Europe as 'lifeless' in Tsiolkas's novel is most likely a confronting one for Europeans. After all, Europeans still pride themselves as being in the centre of Western civilisation. But what does it mean for Europe to be dead? 
According to Tsiolkas the novel is seeking in one way or another to confront three deaths: the death of Yugoslavia; the death of Communism; and the death of Europe's peasant and agrarian class. Moreover, there are numerous other deaths that can be added to the list: the death of ideology, Jews, traditions, nation-states, languages, currencies, buildings, families, refugees, identities, religions, norms, sexualities, and so on. In this context death can also mean change. The question lies in whether the changes that have occurred in Europe over the last two decades have been positive or negative. For readers of Dead Europe the outlook is bleak. At the same time, however, the novel celebrates the fact that Europeans are conscious of the murky morality with which they live on a daily basis. As Isaac's cousin Giulia thunders: 'We finally have some money in our pockets and the bloody immigrant cousin from the New World comes back to tell us how he regrets the changes. What's wrong with fine clothes, fine food, a decent living?' (135). Indeed, there can be no adequate answer to such a question. Death, like a photograph, is fleeting. There is no stopping the forces of change.

Dead Europe is not the first text to deal with alienation in the new Europe. Lukas Moodysson's Lilya 4-Ever (2002) and Mathieu Kassovitz's La Haine (1995) are two of many cinematic examples that highlight different communities living on the European margins. Michael Haneke’s recent film Caché (2005) took this theme one step further by demonstrating that the French denial of responsibility for the treatment of Algerians in its colonial past, and its current treatment of Algerian immigrants, have severe consequences for both the French and the Algerian people. Is it perverse for the former colony to want its former master to share its pain? Again, this is another question that may not be adequately answered. Dead Europe is not seeking to reconcile any of these larger questions. Instead, it reads like an unromanticised travelogue as Isaac photographs alienated peoples in the European continent of 'peace,' 'prosperity,' and 'human rights.'

Although Dead Europe has yet to be published in Europe, Michel Houellebecq's The Possibility of an Island, like all his recent novels, was a European publishing sensation. While Dead Europe chronicles the decay of Europe through a Greek-Australian man's increasingly debauched and transgressive sexual experiences, The Possibility of an Island goes a step further. Houellebecq's novel is a deeply negative vision of modern humanity and his targets include consumer society, sexual commodification, religion 
(especially Islam), democratic politics, and almost everything in between. In a world where people no longer have faith in the philosophical institutions that once served to 'civilise' society, the pursuit of sex is the world's last 'joy' or, at the very least, the only possibility of a momentary feeling of 'happiness.'

The Possibility of an Island tells the story of Daniel, a misanthropic French comedian, who made a fortune 'by acting a complete bastard with impunity' with shows such as 'Munch on my Gaza Strip.’ In a post-ideological world, his liberal audiences do not know whether to be offended or to laud him. After earning millions of euros, Daniel semi-retires in Spain's Almería region because he is tired of the cruelty of laughter. Living alone in a foreign land, Daniel's chief pursuit becomes sex. However, Daniel's sexual conquests only serve to act like a bandaid, covering the meaninglessness underneath. As a result, Daniel joins the Elohimites, a sect that promises immortality through cloning and promotes sexual hedonism and suicide.

From the outset it may seem wanton to discuss two very different novels, one by a Greek-Australian and the other by a Frenchman, in the context of European narratives of peace and suffering, authenticity and cosmopolitanism. However, it can be legitimately argued that both novels contain numerous thematic tropes that can be read, and compared, on a number of levels. Moreover, it can be countered that both novels do not directly deal with European narratives per se. Instead, Europe is merely the geographic setting as the novels slowly follow the stories of their respective protagonists across the European space. Whose Europe do we encounter in these novels? Is it a Europe imagined by the respective authors? Or is it a Europe that we see through the eyes of the novels' main characters? How can we equate Isaac's perceptions of Europe, a gay Greek Australian embarking on a journey of self discovery in Tsiolkas's Dead Europe, with Daniel in The Possibility of an Island, a heterosexual middle aged Frenchman living in Spain’s Almería region? How does my own understanding of Europe affect the reading of these novels? Am I imagining a Europe of my own, constructing a narrative with characters, plots, and action, to fit my own experience of what Europe, is, was, and could be?

I can only respond with the following: every narrative in the end is a form of explanation (Dray 28, 2003). When we ask the questions-what is a story?; what does it 
mean to follow a story?-it is perhaps useful to think of the extent that stories explain ourselves to ourselves. According to Margaret Somers, it matters not whether we are social scientists or subjects of historical research but 'that we come to be who we are (however ephemeral, multiple and changing) by our location (usually unconsciously) in social narratives and networks of relations that are rarely of our own making' (2003, 360). In other words, we are always embedded in social narratives. Whether we recognise it or not, our social identities are constituted through narrativity.

Both Dead Europe and The Possibility of an Island create a textual social reality with varied historical scope. Both novels, however, are complicated by the fact that they use the technique of twin narratives, merging two distinct historical periods into what forms in the end a whole. Both Dead Europe and The Possibility of an Island set one of their narratives threads in twenty-first century post-Communist Europe (as described above). Dead Europe's second narrative, however, looks back to the past spanning the Second World War, the Greek Civil War, and the mass migration of Europeans to Australia in the 1950s. This narrative, a mythological vampiric tale of blood libel, explores the ghosts of the past lurking in the present through the stories of the journey made by Isaac’s parents and grandparents from superstitious and peasant ridden Greek villages, to their experiences as 'wogs' in 'multicultural' Australia. But whereas Tsiolkas's second narrative works as a gothic counterpoint to contextualise Isaac's journey of selfdiscovery, the second narrative of The Possibility of an Island looks forward some two thousand years or so into the future. In Houellebecq's novel, the second narrative is told by the 'neo-humans' Daniel 24 and Daniel 25, the twenty-fourth and twenty-fifth clones of Daniel, who are attempting to reconstruct and understand the life of their predecessor, Daniel 1. The historical span of both novels is therefore immense, circumventing any neat theoretical analysis. But what is apparent, however, is that Europe emerges in both novels as a 'sustained metaphor' (White 2003, 243), at once a historical spectre and a futuristic dystopia. This article seeks to locate and explore this 'sustained metaphor.' Rather than finding the differences between the novels problematic, I posit that these differences can offer a more enriching understanding of the process in which the constituent mythologies of authenticity and cosmopolitanism, peace and suffering, have emerged over the last few decades. 


\section{Contested Narratives}

Can you imagine today's French youth rushing fervently to fight for their country? ... in Europe war has become unthinkable. Not politically. Anthropologically unthinkable. European people are no longer capable of waging war.

Paul in Milan Kundera’s Immortality $(1991,135)$

Despite Michael Hardt and Antonio Negri's compelling argument in Multitude that the September 11 attacks opened a new era of war and that 'war is becoming a general phenomenon, global and interminable,' Europeans do not consider themselves to be operating in a state of 'perpetual war' $(2000,4)$. Instead, one of the founding myths of the new Europe is that of 'perpetual peace,' a narrative that continues to function despite the eruption of the US-led 'War on Terror.' The narrative of perpetual peace is not an overriding narrative in the sense that it obliges all EU member states to always act peacefully and to seek out international justice. Such a narrative could never be objectively demonstrated. Rather, the narrative of 'perpetual peace' has taken on a mythological significance to the European supra-state, a symbolic value that celebrates the dawn of a new European era and that has served to erase the horrors of pre-1945 Europe. In short, Europe without the narrative of 'perpetual peace' is almost unthinkable, even if the narrative does not correspond to geopolitical reality.

Myths, according to Florian Bieber, are at once historical and anti-historical (2002, 97). By this Bieber means that myths are historical in content, being based on real past events; yet the myth itself also has its own history. The narratives of perpetual peace and suffering likewise are myths with a history and anti-history. The idea of Europe as a continent of 'perpetual peace' was first articulated by the US political commentator Robert Kagan in his popular book Paradise and Power (2003). According to Kagan, 'It is time to stop pretending that Europeans and Americans share a common view of the world, or even that they occupy the same world' (2003, 3). Kagan argues that the European outlook is moving beyond power and into a self-contained world of laws and rules and transnational negotiations and cooperation. Unlike the USA, Europe is entering into a post-historical paradise of peace and relative prosperity, the realisation of Immanuel Kant’s 'perpetual peace.’ Kagan is by no means celebrating this utopian vision of a unified Europe. Rather, he sees it as a corollary to Europe's decline in geopolitical power. Put simply, when the European great powers were strong they believed in military power. Now that the European powers are militarily weak they 
champion international law and international institutions.

The success of Kagan's treatise lies in his use of an 'us and them' approach: Americans are from Mars, Europeans are from Venus. This formula has been replicated by other writers who sometimes invert the argument. For example, in The United States of Europe (2005) T. R. Reid sees much to celebrate in the new European Union and wants his fellow Americans to sit up and take notice of the world's new superpower. In Reid's manifesto the world is currently witnessing 'a geopolitical revolution of historic dimensions' (1). As Reid reminds his US readers, '[Europe] has more people, more wealth, and more trade than the United States of America' (1). He points to the emergence of Generation E, a new breed of European who considers the entire continent, and not just one country or city, to be 'home' (199). Whether Euro-optimist or Eurosceptic, the argument always fits into the same narrative script: Europe is unique, increasingly diverging from the hegemonic superpower priorities of the USA. The idea of Europe and the USA being worlds apart is now part of accepted media discourse, reaffirmed on an almost daily basis in the mass media around such important issues as the invasion of Iraq and discussion of the business regulations that govern global industry. According to Reid, the growing sense that the USA is no longer the continent's protector, but rather a potential threat-or even, perhaps, the greatest threat-has strengthened the movement toward 'ever closer union' among the members of the EU (24).

Neither the USA nor the EU are solid entities, and Europe especially remains (geo)politically diverse and contradictory on a range of issues. It is, therefore, not difficult to understand the divergence of interests between Europe and the USA, and by extension the rest of the world. Although European states exported the idea of the border beyond Europe's boundaries as a means of creating a world order in their own image (Nicolaidis and Howse 2002, 770), Europe maintained the aura of being the centre of Western civilisation and the Enlightenment values that it encompassed. This Eurocentrism was not countered successfully until the advent of postcolonial theory in the 1960s and 1970s, when voices from European former colonies, such as Frantz Fanon's The Wretched of the Earth (1961) and Edward Said's Orientalism (1978), began to make inroads in Western scholarship. But despite the emergence of postcolonial scholarship, the burden of European history remained. In Provincializing 
Europe Dipesh Chakrabarty argues that concepts such as 'citizenship, the state, civil society, public sphere, human rights, equality before the law, the individual, distinctions between public and private, the idea of the subject, democracy, popular sovereignty, social justice, scientific rationality, and so on all bear the burden of European thought and history' $(2000,4)$. Chakrabarty is referring here to key concepts in the liberal tradition that postcolonial scholarship needs to engage with in order to ultimately subvert, or at the very least re-imagine, that thought and history.

To what extent, then, does Europe remain Eurocentric? According to Chakrabarty, 'Historians have long acknowledged that the so-called "European age” in modern history began to yield place to other regional and global configurations toward the middle of the twentieth century. European history is no longer seen as embodying anything like a 'universal human history’ (2000,3). There are numerous examples of the 'other' intruding in the European space over the last few decades. The biggest transformation has occurred with mass migration in recent years from Europe's former colonies and other developing countries. But there are also numerous examples to be found in cultural texts, such as Salman Rushdie's novels, which bring the 'third world' into the 'first world.' This 'yielding of place,' as Chakrabarty calls it (2000, 3), has certainly escalated in the postcolonial era. The idea of Europe as no longer representing 'universal human history' is increasingly becoming more noticeable. In the twenty-first century a film can be global without including representations of the European continent. The award winning film directed by González Iñárritu, Babel (2006), is at once celebrated for its ‘globality' and marked by the absent presence of Europe. The only European characters are the British and French tourists in Morocco who are unappreciative of the crisis the American, played by Brad Pitt, is experiencing. Europe, like those tourists, is a bystander, witnessing mass suffering and conflict in the world, but unwilling to sacrifice its comfort zone sufficiently to get itself involved. Yet despite the emergence of other regions over the last century-in not only geo-political and economic measures but also cultural relevance-Europe remains an entity of wonder, an enigma to ponder. With the EU integration process, the 'idea' of Europe (at least in Europe) still occupies centre stage, if not in geo-strategic importance (not many Europeans would dispute the hegemonic superpower status of the USA), but at least in cultural relevance and the preservation of Enlightenment values. The need to define Europe, both in the popular press and in the area of European studies, has become more 
complicated with the European Union integration process and by the fact that now Europe has also become an 'importer' of global realities, as exemplified by the infiltration of global diversity and inequalities into the 'European space' (Nicolaidis and Howse, 2002, 770).

What does 'perpetual peace' mean, however, in a Europe that has recently experienced bombings in Madrid (2004) and London (2005), as well as increasing 'ethnic' conflict (for example, the French riots in late 2005 and the protests that swept some sections of the Muslim world in early 2006 after the Danish newspaper Jyllands-Posten published cartoons depicting the prophet Mohammed)? On the one hand, these events demonstrate that the 'outside' world is already penetrating the European space. But on the other hand, despite the Balkan wars, international and domestic terrorist attacks, race riots, and European participation in the US-led 'War on Terror,' the narrative of 'perpetual peace' is still resonant. Part of the reason for the potency of this narrative is that it operates with the twin narrative of 'perpetual suffering.'

In 'Imagining the Twentieth Century,' David Bruce MacDonald argues that 'as the twentieth century drew to a close, retrospectives entered into fashion ... Written by some of today's leading historians and political scientists, these have attempted, by and large, to portray the twentieth century as the most atrocious in human history, in terms of totalising ideologies, bloodshed, terror, and mass death’ (2007, 1). The problem, MacDonald argues, is that retrospectives have a tendency to downplay or ignore conflict and conquest in earlier centuries. As a result, 'the nineteenth century emerges as an age of moral values, hope, progress and enlightenment—an era squandered only from World War I onwards, leading inexorably to Auschwitz, Vietnam, Cambodia, and Yugoslavia' (1). MacDonald methodically deconstructs the idea of the twentieth century as being the most 'atrocious' in history, and mounts a convincing argument against that idea by highlighting the destructive legacy of colonialism in previous centuries, and by citing the genocide of the indigenous populations in the Americas and Australia. But the important point of MacDonald's argument, in my view, is not whether or not the twentieth century was the most destructive in history, but why it is imagined to be so. As Shelley Wright argues the difference between the pre and post-Holocaust world is not that the world has necessarily become any more violent or evil. Rather, the Holocaust has forced us to 'understand that the violence of ethnic tribalism is not 
confined to Africa, or Asia, or the Middle East, or the cities of Eastern Europe-it is here, at home-We are the Savage' (Wright 2001, 18-9). Europe has thus taken on board the 'evil' of the twentieth century and narrativised it through various modes of commemoration and fin de siecle memoirs. Thus evil is somehow intrinsically linked to the European space, since some of the worst excesses of the twentieth century occurred on European soil, the geographic location of the First World War, most of the Second World War, the Holocaust, fascist dictatorial regimes, the oppressive Soviet Union and its satellite states, civil wars, ethnic tensions and economic devastations. When this historical context is taken into account, the EU project is nothing short of remarkable. The ex-UK Prime Minister Tony Blair acknowledged the historic dimensions of the EU integration process when complaining about the tediousness of EU summits:

\footnotetext{
They do go on a bit. You know, these summits make sense if you try to have a sense of history. I mean, when the thing is getting tiresome, you have to remember what we are doing here. We are building a new world superpower. The European Union is about the projection of collective power, wealth and influence. That collective strength makes individual nations more powerfuland it will make the EU as a whole a global power. (quoted in Reid 2005, 2)
}

In the narrativisation of the twentieth century as essentially a 'European' century of 'total' war, it is not surprising that the narrative script of post-1989 Europe is that of 'total' or 'perpetual' peace. And this narrative script is sustained by its twin narrative of perpetual suffering: Europe now has peace because it has suffered. This is a logical equation, but also one that may be subverted, as my discussion of the two novels will suggest. The narrative of 'perpetual suffering' might be news to Aboriginal Australians, to the peoples of East Timor, Rwanda, Nicaragua, Burma, and countless other localities of suffering and destruction where havoc has been wreaked on domestic populations. But according to MacDonald, this underlines the trend, as Chakrabarty has also noted, 'of putting 'Europe first, the rest of the world later' (2000, 2). The European Union integration process continues the narratives of the Enlightenment and the nineteenth century, skipping over the trauma of the twentieth century as more or less an historical glitch. The perpetuity of suffering is not erased, nor forgotten; rather it is commemorated, sustaining and validating the narrative of 'perpetual peace.'

\section{A post-historical EUtopia}

Il faut être absolument moderne Arthur Rimbaud, Une Saison en Enfer
We have to be utterly modern. Arthur Rimbaud, A Season in Hell 
In Europe almost every truism can be challenged and deconstructed: the nation-state, the border, the citizen, the immigrant, the intellectual, the peasant, the terrorist, the nationalist, the war criminal. Everything in Europe can be negated, turned in on itself, self-cannibalised. In the opinion pages of Europe's serious newspapers, intellectuals are given free reign to imagine Europe as a negation. Europe is not ...

One of the more recent and interesting critical approaches in imagining 'Europe' has been by Nicolaidis and Howse who argue that the EU is a civilian power promoting an 'EUtopia' through narratives of projection (Nicolaidis and Howse 2002). That is, the EU seeks to 'reproduce' itself 'by encouraging regional integration around the world' (2002, 768). Nicolaidis and Howse argue that 'narratives of projection' are extremely fruitful, but warn that 'exercises in projection often lack the kind of self-awareness that would lead us to recognise how "what" is being projected is not the EU as is but an “EU-topia” (768). And that utopia itself is necessarily a contested one, and not everyone's vision of the EU's future. What EU is being projected becomes critical' (769). In conclusion, the authors posit that the only way that the EU can become a meaningful utopia is by 'bringing the outside world back in' (769). A cursory glance at recent scholarship and popular culture, however, demonstrates that the outside world is already inside the European space on all fronts: academically, culturally, economically, and politically. It is not a matter of 'bringing the outside world back in' but of accommodating the 'other' already within, and which EU member states have been slow in recognising.

Another interesting approach was articulated by Jacques Derrida in 'A Europe of Hope,' published in Le Monde Diplomatique in November 2004. Derrida attempted to conceptualise a new 'Europe' that could criticise every manifestation of Eurocentrism without, however, rejecting or leaving Europe altogether $(2005,15)$. In Michael Naas’s reading of 'A Europe of Hope':

Derrida would thus seem to be gesturing toward a Europe with a particular tradition, a particular language - or particular languages, beginning with Greek and Latin—and a particular history, but a Europe that then calls out for or calls us toward a Europe that exceeds any particular European or Eurocentric vision, a Europe that might be rooted in certain European ideals, notably those of the Enlightenment (democracy, freedom of thought and expression, freedom of the press, liberal education and so on), but that would call all those who hear the promise and hope of these values beyond their current understanding and deployment-whether in what is called Europe today or anywhere else in the world. 'A Europe of Hope' would thus refer at once to this historical thing called Europe, this continent identifiable on a map, and to a Europe that 
remains to come-not only in France or Germany, Italy or Spain, but in the United States or Australia, in Algeria or China. $(2005,6)$

Thus, Naas argues, the 'only real solution for the future, of actually thinking through and reflecting upon Europe today not in order to say "yes” or "no" to it, but so as to criticise what has to be criticised within it and to realise the best of what it has promised' (2005, 23). Both Derrida and Nicolaidis and Howse thus argue that although a European ideal might begin with Europe, it must then seek to engage with ideas outside of Europe, accommodating the best of European thought and tradition with the best that the rest of the world has to offer. A 'Europe of Hope' is, according to Naas, a Europe of endless, critical reflection, of analysis and discussion (Naas 2005, 22).

Dead Europe and The Possibility of an Island do not promote a 'vision' of Europe, but rather, in Derrida’s terms, a 'discussion.' Both novels, however, highlight that Europe does not have to 'bring the outside world back in,' but rather has to acknowledge that the outside world is already within the European space, blurring a multitude of borders, spaces and frontiers. In Dead Europe and The Possibility of an Island, the idea of Europe as embodying 'universal human history’ is ‘dead.' Yet whereas Dead Europe carries the burden of European thought and history to the extent that Tsiolkas must engage with European histories and ideas in order to ultimately subvert them, The Possibility of an Island is marked by the absence of these historical burdens.

The Possibility of an Island demonstrates that political ideology has been superseded by the culture of youth and image. Daniel is a victim of the fallout from the 1960s' sexual revolution: alienated by consumerism, incapable of belief, and prisoner to his restless desire (Adams 2005, 15). The Possibility of an Island whilst evidently a scalding social critique of contemporary European society is, according to Robert Peluso, more than anything an attack on philosophical materialism, with 'its favouring of rationality over sensualism, its glorification of the imperial individual over the collective human being and its predilection for seduction and domination rather than unselfish love and goodwill' (2006, F-6). In Dead Europe, the outsiders are the underclass of refugees and migrants from Europe's former colonies. In The Possibility of an Island, however, any European who does not find glory in the 'imperial individual' is an outsider. In Houellebecq's narrative, therefore, almost everyone over the age of forty is superfluous. Although Daniel is disgusted by this 'generational holocaust,' he views such moral 
abominations as a natural outgrowth—even an evolutionary step—of a modern consumer culture fixated on the young (Schacht 2006).

In Dead Europe, Tsiolkas presents a post-communist Europe free of political ideology, where the remnants of the political left and right are anachronisms in a world where 'the Sunday papers can have travel lift-outs extolling the virtues of cosmopolitan Prague when a few miles down the road you can buy a young girl for sex for a few American dollars’ (2007). Yet this collapse in ideological fervour in Europe did not necessarily mean that 'history' had ended or that liberalism triumphed, as writers such as Francis Fukuyama (1992) argued in the early 1990s. According to Humphrey McQueen (2005), the triumphalism on the Right, and the disarray on the Left, blinded both sides to a third possibility: 'The End of History as a clash of modernising Ideas did not leave the field free for capitalism. Rather, the End of History allowed for a resurgence of the peasant with her superstitions, her rituals of blood and soil. Capitalism might have beaten off the future, but it has yet to vanquish the past. That much should have been clear in 1989' (2005). Tsiolkas exposes in Dead Europe the cult of superstition flourishing in a continent that is the supposed home of rationality and science. The unavoidable allegory to draw, according to Syson, 'is that something horrific is also stored in Europe, with its long dark sleeping hatreds and terrible festivals of war, blood and slaughter' $(2005,4)$. In Dead Europe, just like in Michael Haneke’s film Caché (2005), those sleeping demons are awoken with terrifying consequences. Dead Europe is an obituary for the cheery optimism that swept Europe in the aftermath of the fall of the Berlin Wall.

Isaac's (and to a certain extent Daniel's) descent into 'A Season in Hell' is also a threnody for the loss of 'authentic' European culture. The Mediterranean culture that was once concerned with the enjoyment of life and expansive notions of community has been replaced by a 'Western' mass culture obsessed with consumption and excess.

According to Tsiolkas:

As the nation becomes more westernised there are more and more people finding themselves alienated from the new Europe ... Travel anywhere in the EU and you are confronted by the mass of refugees and migrants. So at the same time we are supposedly global and connected through the Net and through commerce we are also building detention centres and creating laws that are about sealing ourselves off from those in exile. (2007)

As a 'sustained metaphor' this threnody of loss extends to all local cultures of the 
European Union that are being disseminated in the name of creating a uniform and homogenous supra-state.

\section{Deadly Possibilities}

If the overarching theme of both novels is moral decadence, that decadence is pathologised by both Tsiolkas and Houellebecq as a modern syndrome, in that to be modern means 'never being satisfied.' According to Tsiolkas, 'I think Australians and Europeans and the Americans are now truly decadent cultures. There is a danger in excess and the danger is a spiritual and moral emptiness' (2007). This syndrome is an illness that subverts the rationality of cosmopolitan E-generation Europeans. Tsiolkas’s and Houellebecq's novels challenge the idea that cosmopolitan Europe is functioning successfully alongside the 'authentic' traditions of European nations. Instead, there are two Europes - a connected Europe and a disconnected Europe - and both Europes are increasingly in confrontation.

'Connected Europe' refers to a new generation of cosmopolitan Europeans who are amoral, free, decadent, living in the present, and not tied to any traceable subjectivities from the past. These Europeans are aware of the horrors and atrocities that occurred on European soil in the twentieth century but feel neither responsible for them, nor the burden of that history. Instead, these Europeans are 'connected' to each other, online and through social networks, and have more in common with each other than with the weight of their shared histories. 'Disconnected Europe,' on the other hand, refers to a Europe that is removed from these social networks. These Europeans are not necessarily 'disconnected' from the increasing 'decadence' and 'excess' that Tsiolkas's and Houellebecq's novels are criticising. Rather these Europeans feel the weight of their national history and the burden of the narratives of the twentieth century.

Both Tsiolkas and Houellebecq suggest that the difference between 'connected' and ‘disconnected' Europe lies between generations. Tsiolkas laments the passing of 'disconnected Europe' to 'connected Europe,' and seems to suggest that an acknowledgement of this 'loss' is becoming ever more pressing and urgent. This is because the EU that is being unified is a Western Europe, leading to many other histories in Europe being forgotten. Thus, Tsiolkas argues, 'Europe has to remember its history as being Christian, Jewish and Muslim. It has to remember the Byzantine 
Empire as much as it remembers the Holy Roman Empire' (2007). On the other hand, in The Possibility of an Island, Houellebecq seems to suggest that because the idea that Europe embodies 'universal human history’ has become redundant, Europe has entered into a new epoch of such historic dimensions that the morality and historical narratives of the past are no longer relevant. Houellebecq's novel, like Arthur Rimbaud before him, challenges us to be utterly modern. Of course, what it means to be modern is constantly changing. Daniel, the narrator in The Possibility of an Island, views history marching forward without him, leaving him feeling alienated. Unlike Tsiolkas, however, The Possibility of an Island suggests that there should be no lamentations for this state of affairs, that the only solution is a 'final solution.' The old citizens, ideas and myths (including Daniel) must die and let Europe connect to the global Empire regardless of the consequences. There is no stopping modernity.

According to John Schacht, 'If, as John Donne wrote, 'no man is an island,' the possibility of one suggests that the sacrifices made to get there come with a hefty price tag: Our common humanity' (2006). The Possibility of a Dead Europe is a Europe where the cult of the individual has emerged as the new imperium. In America, Jean Baudrillard wrote:

In the very heartland of wealth and liberation, you always hear the same question: 'What are you doing after the orgy?' What do you do when everything is available—sex, flowers, the stereotypes of life and death? This is America's problem and, through America, it has become the whole world's problem. $(1988,30)$

It has indeed become the world's problem, especially Europe's. As Baudrillard further reflects, 'liberation has left everyone in an undefined state (it is always the same once you are liberated, you are forced to ask who you are)' (1988, 46). Isaac in Dead Europe leaves Australia, a land of people still searching for a common identity, only to land in Europe to discover a continent actually living Kagan’s post-historical paradise, but unable to answer the age old questions: Who am I?, and, Where do I come from? As one Australian reviewer of Dead Europe asked, what is the place of Australia in a world where Europe is dead? What happens to antipodeans when their other pole is no more (McQueen 2005)? The other pole that is no more, is the 'authentic,' disconnected Europe that remains in the imagination of Europe's former colonies and exiles.

By the end of Dead Europe, Isaac is so consumed by the past that it almost kills him. 
Beneath Europe's post-historical paradise lie the phantoms that 'connected' Europe is refusing to acknowledge and which have the potential to undermine powerful European mythologies that have so far served to create what Tony Blair calls a new global power. In the end, Isaac is restored to life by being brought back to Australia. His rescue depends on several kinds of love as much as on geography (McQueen 2005). The story of Daniel, on the other hand, does not have such a fitting ending. A post-historical paradise as conceived by Houellebecq is, in the end, a dystopia. The neohuman narrations demonstrate that the frictionless existence of their perfectly modulated universe created by human reason is a living hell devoid of affection and meaning (Peluso 2006, F-6).

\section{Conclusion}

In Europe today, to be utterly modern is to live in 'perpetual peace,' acknowledge the horrors of the 'European Century,' and enjoy cosmopolitan lifestyles, yet at the same time to celebrate 'national' diversities. These mythologies cannot be objectively demonstrated; nonetheless they function discursively in order to erase the horrors of the twentieth century. It cannot be disputed that the European Union project has been immensely successful in promoting these mythologies. Any serious challenges to these mythologies, such as the recent invasion of Iraq in 2003, lead to a mass mobilisation of European peoples on the streets in protest. The re-emergence of far-right political parties, which also have the potential to undermine these mythologies, has so far been relegated to the margins of European society. Dead Europe and The Possibility of an Island, however, highlight that beneath these mythologies lie two significant tensions. The first is that underneath Europe's post-historical paradise lurk the national stories and histories of the peoples being forgotten in the EU integration process. These stories must be acknowledged if the European Union is to be true to the ideals of equality and justice. The second fundamental tension is that the EU is successfully accommodating both a cosmopolitan E-generation Europe and the values and traditions of 'authentic' Europe. Tsiolkas and Houellebecq demonstrate, albeit in different ways, that to be utterly modern means bringing these two different Europes into confrontation. Yet, in the end, although both novels do not offer us a satisfying resolution to the 'big themes,' they do promote a worthwhile discussion. Although Isaac's photographs chronicle authentic Europe's slow death, his cousin Giulia is there once again to remind us that it is impossible to know where modernity will take us: 'this place has been here for 
thousands of years and it will be here when your euro and your EU and your fucking

NATO will be just memories ...' (Tsiolkas 2005, 106). It's hard to argue against that.

\section{Reference List}

Adams, T. 2005, 'The Book of Daniels,' The Observer, October 30, 15.

Baudrillard, J. 1988, America, Verso, London.

Beck, U. 2003, 'Understanding the Real Europe,' Dissent, Summer. [Online]. Available: http://www.dissentmagazine.org/article/?article=483 [accessed 3 January, 2007].

Bieber, F. 2002, 'Nationalist Mobilization and Stories of Serb Suffering: The Kosovo Myth from 600th Anniversary to the Present,' Rethinking History, vol. 6, no. 1 (Spring), 95-110.

Chakrabarty, D. 2000, Provincializing Europe: Postcolonial Thought and Historical Difference Princeton, NJ, Princeton University Press.

Derrida, J. 2004, 'Une Europe de l'espoir,' Le Monde Diplomatique, November, 3.

Dray, W. H. 2003, 'On the Nature and Role of Narrative in History,' in G. Roberts (ed.), The History and Narrative Reader, Routledge, London, 25-39.

Fanon, F. 1967, The Wretched of the Earth, Penguin, Harmondsworth.

Fukuyama, F. 1992, The End of History and the Last Man, Free Press, New York.

González Iñárritu, A. (dir.) 2006, Babel, Anonymous Content.

Haneke, M. (dir.) 2005, Caché, Les Films du Losange.

Hardt, M. and Negri, A. 2004, Multitude, Hamish Hamilton, London.

Houellebecq, M. 2006, The Possibility of an Island, Phoenix, London.

Kagan, R. 2003, Paradise and Power: America and Europe in the New World Order, Atlantic Books, London.

Kassovitz, M. (dir.) 1995, La Haine, Canal+.

Kundera, M. 1991, Immortality, Faber and Faber, London.

MacDonald, D. B. 2007, 'Rethinking the Twentieth Century: Retrospective, Myth and the Colonial Question,' PORTAL: Journal of Multidisciplinary International Studies, vol. 4, no. 1. January. [Online]. Available: http://epress.lib.uts.edu.au/ojs/index.php/portal/editor/issueToc/28_[accessed 3 March, 2007].

McQueen, H. 2005, 'Review of Christos Tsiolkas, Dead Europe,' Politics and Culture, no. 4. [Online]. Available: http://aspen.conncoll.edu/politicsandculture/ [accessed 3 January, 2007].

Moodysson, L. 2002, Lilya 4-ever, Zentropa Entertainments.

Naas, M. 2005, ‘A Last Call for ‘Europe,’ Theory \& Event, vol. 8, no. 1 [Online]. Available: http://muse.jhu.edu/journals/theory_and_event/toc/archive.html\#8.1 [accessed 3 January, 2007].

Nicolaidis, K. \& Howse, R. 2002, “'This is my EUtopia ...': Narrative as Power,' Journal of Common Market Studies, vol. 40, no. 4, 767-92.

Peluso, R. 2006, 'The Book of Daniels: Houellebecq Novel Focuses on Comedian and His Two Clones,' Pittsburgh Post-Gazette, October 8, F-6.

Reid, T. R. 2005, The United States of Europe: The New Superpower and the End of American Supremacy, Penguin Press, New York.

Rimbaud, A. 2001, Collected Poems, Oxford University Press, Oxford.

Said, E. 1978, Orientalism, London, Routledge \& Kegan Paul.

Schacht, J. 2006, 'The Possibility of an Island by Michel Houellebecq,' Pop Matters, 22 May. [Online]. Available: http://www.popmatters.com/books/reviews/p/possibility-of-an-island.shtml, accessed 20 March, 2007.

Somers, M. 2003, 'Narrative, Narrative Identity, and Social Action: Rethinking English Working-Class Formation,' in G. Roberts (ed.), The History and Narrative Reader, Routledge, London, 354-74.

Syson, I. 2005, 'A Taste of European Decay,' The Age, May 28, 4.

Tsiolkas, C. 2005, Dead Europe, Vintage, Sydney.

Tsiolkas, C. 2007, 'Q\&A with Christos Tsiolkas,' Random House (Australia) press release, 3 January.

White, H. 2003, 'The Historical Text as Literary Artifact,' in G. Roberts (ed.), The History and Narrative Reader, Routledge, London, 221-36.

Wright, S. 2001, International Human Rights, Decolonization and Globalization: Becoming Human, Routledge, New York. 